Tarbawy : Jurnal Pendidikan Islam

ISSN : 2407-4462 (Cetak), 2614-5812 (Elektronik)

Vol. 8, No. 2, 2021, Hal. 8-15

DOI: https://doi.org/10.32923/tarbawy.v8i2.1793

\title{
Efektivitas Pendidikan Agama Islam Pada Anak Usia Dini
}

\author{
Alif Fajri A. ${ }^{1}$, Delly Arhadath. ${ }^{2}$, Slamet Muliono R. ${ }^{3}$ \\ ${ }^{1}$ STAI Ali bin Abi Thalib \\ ${ }^{2}$ STAI Ali bin Abi Thalib \\ ${ }^{3}$ STAI Ali bin Abi Thalib
}

Info Artikel :

Diterima 1 juli 2021

Direvisi 13 Agustus, 2021

Dipublikasikan 21 oktober 2021

\section{Kata Kunci: \\ Efektivitas \\ Pendidikan Agama Islam \\ Anak Usia Dini}

\section{Keywords:}

Effectiveness

Basic Islamic Education

Children

\author{
Koresponden: \\ Alif fajri \\ Aliffajri96@gmail.com
}

\begin{abstract}
ABSTRAK
Manusia adalah makhluk hidup yang selalu memerlukan pendidikan agar hidupnya dapat berjalan lurus terutama pendidikan agama sebagai pedoman hidup. Pendidikan agama ini harus dilaksanakan sejak manusia masih berusia dini, dalam artian masih anak-anak, karena pemberian pendidikan agama pada masa anak-anak merupakan dasar yang sangat berarti bagi pembentukan dan pembinaan agama manusia. Tujuan dari penelitian ini yaitu dapat mengetahui seberapa efektifnya pendidikan agama islam diberikan pada anak sejak usia dini. Penelitian ini dilakukan secara kualitatif menggunakan metode studi literature atau penelitian kepustakaan yang akan dianalisis dan disimpulkan. Teknik pengumpulan data yang digunakan yaitu studi literature, yang diperoleh berdasarkan penggalian, penemuan, pembacaan dan penjelasan makna dari dari berbagai buku-buku referensi, jurnal ilmiah, majalah dan sumber pustaka lainnya yang berkaitan dengan pendidikan islam pada anak usia dini. Dari hasil studi literatur dapat kita simpulkan bahwa pembelajaran agama islam yang diberikan kepada anak usia dini berjalan efektif dan terlihat signifikan dengan adanya peningkatan dari hasil belajar dan proses hasil wawancara dengan pihak orangtua. Oleh karena itu pembelajaran Agama Islam dapat diberikan dari anak usia dini secara teratur dan berkesinambungan untuk melihat perkembangan fungsi otak mereka, otak pada anak usia dini berkembang dengan pesat sehingga proses penyerapan ilmu pendidikan lebih mudah.
\end{abstract}

\begin{abstract}
Humans are living beings who always need education so that their lives can go straight, especially religious education as a way of life. This religious education must be carried out since humans are still at an early age, in the sense that they are still children, because the provision of religious education during childhood is a very meaningful basis for the formation and development of human religion. The purpose of this study is to find out how effective Islamic religious education is given to children from an early age. This research was conducted qualitatively using the method of literature study or library research to be analyzed and concluded. The data collection technique used is literature study, which is obtained based on excavation, discovery, reading and explanation of the meaning of various reference books, scientific journals, magazines and other library sources related to Islamic education in early childhood. From the results of the literature study, we can conclude that Islamic religious learning given to early childhood is effective and looks significant with an increase in learning outcomes and the process of interviewing the parents. Therefore, Islamic learning can be given from early childhood on a regular and continuous basis to see the development of their brain function, the brain in early childhood develops rapidly so that the process of absorbing educational knowledge is easier.
\end{abstract} This is an open access article distributed under the Creative Commons Attribution License,
which permits unrestricted use, distribution, and reproduction in any medium, provided the original work is properly cited. 12019 by author.

\section{Pendahuluan}

Manusia adalah makhluk hidup yang selalu memerlukan pendidikan agar hidupnya dapat berjalan lurus terutama pendidikan agama sebagai pedoman hidup. Pendidikan agama islam merupakan bimbingan yang diberikan kepada seseorang agar kehidupannya berjalan sesuai dengan hakikat agama islam. Pendidikan agama ini harus dilaksanakan sejak manusia masih berusia dini, 
dalam artian masih anak-anak, karena pemberian pendidikan agama pada masa anak-anak merupakan dasar yang sangat berarti bagi pembentukan dan pembinaan agama manusia.

Setiap orang tua mempunyai kewajiban dalam memberikan pendidikan agama islam kepada anak-anaknya agar menjadi anak yang sholeh. Ajaran islam mengajarkan bahwa anak merupakan fitrah yang mana harus kita jaga agar menjadi anak yang memiliki jiwa yang baik dalam islam, berguna didunia dan diakhirat. Dalam memenuhi hal tersebut orang tua harus membentuk kepribadian anak dengan memberikan pendidikan agama. Selain dari orangtua, mereka juga memerlukan bantuan dari lembaga-lembaga pendidikan fomal ataupun no-formal lainnya seperti PAUD/TK/TPA dan sebagainya. Agar mereka mendapatkan ilmu yang lebih luas untuk kedepannya.

Pendidikan agama ini harus dilakukan dari anak usia dini karena anak lebih mudah menerima, menyerap, merespon, dan meniru, sesuatu yang diajarkan baik dalam bentuk ungkapan, ucapan dan pengalaman penginderaan sehingga lebih mudah membentuk kepribadian anak kedepannya. Oleh karena itu setiap lembaga pendidikan harus menciptakan pembelajaran yang efektif dengan pengelolaan pendidikan agama yang baik. Kegiatan pembelajran harus dilakukan dengan menggunakan keafktifan anak, menggunakan berbagai metode yang membuat anak tidak bosan, dikarenakan pada usia dini anak-anak lebih senang bermain daripada belajar untuk serius maka dalam pembelajarannya juga harus diselingi dengan berbagai permainan sehingga mereka dapat memahami dengan baik.

Untuk menciptakan pembelajaran yang efektif, kegiatan pembelajaran dilembaga pendidikan mengharuskan seorang guru harus mendekatkan diri kepada anak didiknya sehingga dapat meningkatkan interaksi antar mereka dan membuat anak lebih aktif dalam menerima berbagai pembelajaran. Interaksi yang baik dapat digambarkan dengan suatu keadaan di mana guru dapat membuat anak didiknya belajar dengan mudah dan terdorong untuk mempelajari apa yang menjadi kompetensi yang ditentukan sekolah sebagai bekal untuk masa depan mereka. Untuk mewujudkan hal tersebut, maka dalam pembelajaran Pendidikan Agama Islam hendaknya menjabarkan nilainilai yang terkandung dalam materi dan mengkorelasikan dengan kenyataan yang dialami mereka dalam kehidupannya.

Pemberian pendidikan pada anak usia dini akan membantu proses perkembangan mereka. Menurut Chaplin dalam (Desmita,2014) bahwa "Perkembangan diartikan sebagai perubahan yang berkesinambungan dan progresif dalam organisme, dari lahir sampai mati; pertumbuhan; perubahan dalam bentuk dan dalam integrasi dari bagian-bagian jasmaniah ke dalam bagian-bagian fungsional; kedewasaan atau kemunculan pola-pola asasi dari tingkah laku yang dipelajari" sehingga dalam memberikan pendidikan perlu disesuaikan dengan aspek perkembangan anak. Dengan adanya pendidikan agama islam pada anak kita dapat melihat seberapa efektifnya pendidikan agama islam ini diberikan pada anak usia dini.

\section{Metodelogi}

Penelitian ini dilakukan secara kualitatif, yaitu penelitian yang digunakan untuk menyelidiki, menemukan, menggambarkan, dan menjelaskan dari suatu permasalahan dengan cara mengumpulkan informasi dari berbagai sumber ${ }^{1}$. Teknik pengumpulan data yang digunakan yaitu studi literature, yang diperoleh berdasarkan penggalian, penemuan, pembacaan dan penjelasan makna dari dari berbagai buku-buku referensi, jurnal ilmiah, majalah dan sumber pustaka lainnya yang berkaitan dengan pendidikan islam pada anak usia dini².

Teknik ini dilakukan dengan tujuan untuk mengungkapkan berbagai teori-teori yang relevan dengan permasalahan yang sedang dihadapi/diteliti sebagai bahan rujukan dalam pembahasan hasil penelitian. Pengertian Lain tentang Studi literatur adalah mencari referensi teori yang relefan dengan kasus atau permasalahan yang ditemukan.

\section{Pembahasan}

\section{Pendidikan Anak Dalam Islam}

\footnotetext{
${ }^{1}$ Sugiyono. 2011. Metode Penelitian Kuantitatif, Kualitatif dan R\&D. Bandung: Afabeta

${ }^{2}$ Danial dan Wasriah. 2009. Metode Penulisan Karya Ilmiah. Bandung: Laboratorium Pendidikan Kewarganegaraan UPI.
} 
Pendidikan Agama Islam adalah proses mengubah tingkah laku individu peserta didik pada kehidupan pribadi, masyarakat, dan alam sekitarnya. Proses tersebut dilakukan dengan cara pendidikan dan pengajaran sebagai suatu aktivitas asasi dan profesi di antara sekian banyak profesi asasi dalam masyarakat ${ }^{3}$.

Dasar pendidikan Islam ialah Islam dengan segala ajarannya yang tertuang dalam Al Quran dan Sunnah (hadis) Rasulullah SAW. Penetapan Al Qur-an dan Hadis sebagai dasar pendidikan Islam, hal ini dikarenakan kebenaran yang terdapat dalam kedua dasar tersebut dapat diterima oleh nalar manusia dan dapat dibuktikan dalam sejarah atau pengalaman kemanusiaan. ${ }^{4}$ Sebagai pedoman, Al Qur-an tidak ada keraguan padanya, terpelihara kesucian dan kebenarannya. Demikian juga dengan kebenaran hadis sebagai dasar kedua bagi pendidikan Islam.

Anak merupakan amanah bagi orangtua yang harus mendapatkan didikan yang baik sehingga dapat tumbuh berkembang dengan baik sesuai dengan ajaran islam. Dalam neurosains dijelaskan bahwa anak yang baru lahir mempunyai 100-200 miliyar neuron $^{5}$. Pada usia dua tahun perkembangan otaknya telah mencapai $75 \%$, pada usia 5 tahun perkembangan otaknya telah mencapai $90 \%$ dan pada 10 tahun perkembangan otaknya telah mencapai $99 \%{ }^{6}$. Oleh karena itu pendidikan agama yang baik dimulai dari anak pada usia dini dibiasakan dan dididik dengan hal-hal yang baik dan diajarkan kebaikan kepadanya, ia akan tumbuh dan berkembang dengan baik dan akan memperoleh kebahagiaan serta terhindar dari kesengaraan/siksa baik dalam hidupnya di dunia maupun di akhirat kelak. Hal ini senada dengan firman Allah:

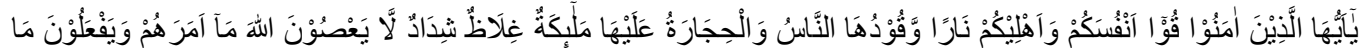

$$
\begin{aligned}
& \text { يُوَْْرُوْنَنَ }
\end{aligned}
$$

Artinya : "Wahai orang-orang yang beriman! Peliharalah dirimu dan keluargamu dari api neraka yang bahan bakarnya adalah manusia dan batu; penjaganya malaikat-malaikat yang kasar, dan keras, yang tidak durhaka kepada Allah terhadap apa yang Dia perintahkan kepada mereka dan selalu mengerjakan apa yang diperintahkan" (QS. At-Tahrim : 6)

Ayat diatas menggambarkan bahwa pendidikan harus bermula dari keluarga, dimana orang tua harus bertanggung jawab penuh atas keluarga dan anak-anaknya dari siksaan api neraka. Dengan memberikan pendidikan untuk mengikuti perintah Allah SWT dan menjauhi larangan-Nya agar anak terlindungi dari marabahaya baik didunia maupun diakhirat nanti. Kemudian orang tua juga harus mengawasi pertumbuhan anaknya sejak dini dengan cermat dan bijak sesuai dengan tuntutan agama islam. ${ }^{7}$

Dari uraian diatas dapat disimpulkan bahwa tujuan pendidikan agama islam yaitu memilihara, melindungi, membantu masa pertumbuhan, dan perkembangan fitrah sehingga jiwa anak terlahir dalam kondisi fitrah dalam kata lain terkandung nilai-nilai keislaman sehinga dalam perkembangan selanjutnya anak menjadi manusia muslim yang kāffah, yang beriman dan bertaqwa kepada Allah SWT. Hidupnya terhindar dari kemaksiatan, dan dihiasi dengan ketaatan dan kepatuhan serta oleh amal soleh yang tiada hentinya.

Selain dari keluarga, pendidikan harus dilakukan melalui 3 lingkungan yaitu lembaga pendidikan dan masyarakat. Lembaga pendidikan berpusat dalam memberikan pendidikan keagamaan secara luas, sedangkan masyarakat melalui sifat dan karakter ${ }^{8}$.

2. Fungsi dan tujuan pembelajaran agama islam

Sesuai dengan hakikat pendidikan Islam yang merupakan suatu proses yang berlangsung secara kontiniu maka fungsi dari pendidikan Islam yaitu memberikan

\footnotetext{
${ }^{3}$ Omar Mohammad Al-Thoumy Al-Syaibany,1979. Filsafat Pendidikan Islam, Terjemahan Hasan Langgulung, Jakarta: Bulan Bintang

${ }^{4}$ Lihat Abuddin Nata,1999. Metodologi Study Islam, Cet. I; Jakarta: PT. Raja Grapindo Persada

${ }^{5}$ Pasiak, Taufik. 2009. Unlimited Potency of The Brain: Kenali dan Manfaatkan. Sepenuhnya Potensi Otak Anda yang Terbatas. Bandung: PT Mizan.

${ }^{6}$ Suyadi. 2014. Teori Pembelajaran Anak Usia Dini. Bandung : PT. Remaja

${ }^{7}$ Anonim, Al-qur'an terjemahan.

${ }^{8}$ Isjoni,2010. Model Pembelajaran Anak Usia Dini Bandung: Alfabeta
} 
pendidikan manusia seutuhnya dan berlangsung sepanjang hayat ${ }^{9}$. Konsep ini bermakna bahwa fungsi pendidikan memiliki sasaran pada anak-anak yang senantiasa tumbuh dan berkembang secara dinamis, sejak masih dalam kandungan sampai ajal menjemputnya. Berikut fungsi pembelajaran agama islam, yaitu ${ }^{10}$.

a. Fungsi Pengembangan yaitu sebagai proses pengembangan karakter keimanan kepada Allah SWT sesuai dengan ajaran Islam yang sebelumnya telah ditanamkan dalam keluarga.

b. Fungsi Penanaman yaitu sebagai pedoman hidup dalam dunia maupun akhirat sehingga terlindungi dari marabahaya.

c. Persiapan mental yaitu untuk menyesuaikan diri dengan lingkungannya baik lingkungan fisik maupun lingkungan sosial sesuai dengan ajaran Islam pada setiap lingkungannya.

d. Rehabilitasi yaitu untuk memperbaiki kesalahan, kekurangan, dan kelemahan anak-anak dalam pemahaman, keyakinan dan pengamalan ajaran dalam laku kehidupan seharihari.

e. Pencegahan yaitu untuk menghindarkan anak dari pengaruh negatif ataupun perbuatan buruk dari lingkungannya atau dari budaya lain.

Jadi fungsi dari pembelajaran agama islam pada anak usia dini yaitu meningkatkan kualitas moral keimanan serta ketakwaan seorang anak sejak usia dini kepada Allah SWT untuk mencari kebahagian dunia dan akhirat.

Sedangkan tujuan Pendidikan Agama Islam yaitu untuk meningkatkan keimanan, pemahaman, penghayatan, dan pengamalan peserta didik tentang Agama Islam sehingga menjadi seseorang yang beriman dan bertakwa kepada Allah serta berakhlak mulia dalam kehidupan pribadi, bermasyarakat, berbangsa dan bernegara. Berikut tujuan pembelajaran agama islam ${ }^{11}$ :

a. Membentuk moral dan akhlak yang mulia.

b. Persiapan untuk kehidupan dunia dan kehidupan akhirat.

c. Menumbuhkan semangat ilmiah pada anak dengan memuaskan keinginan untuk mengetahui dan memungkinkan ia mengkaji ilmu demi ilmu itu sendiri.

Dengan demikian dapat dipahami bahwa tujuan pembelajaran Agama Islam yaitu untuk membentuk pribadi yang beriman dan bertakwa kepada Allah dan senantiasa meningkatkan keimanannya melalui pemupukan pengetahuan serta pengalamannya tentang agama Islam sehingga menjadi manusia muslim yang terus berkembang dalam hal keimanan dan ketakwaannya dalam berbangsa dan bernegara sehingga tercapai kebahagiaan di dunia dan di akhirat.

3. Metode Pembelajaran dalam PAUD

Guru sebagai pendidik kedua setelah orangtua bertanggung jawab dalam mendidik, membimbing, dan mengasuh anak-anak di sekolah, keberhasilan guru dalam melaksanakan tugasnya akan memberi hasil kepada anak-anak usia emas. ${ }^{12}$ Menurut Fadhli Ilahi (2003), untuk menjadi guru yang profesional dalam mendidik anak usia dini, hendaklah menggunakan dua bentuk pengajaran yang dilakukan Rasulullah yaitu: ${ }^{13}$

1. Mengajari dengan perbuatan, seseorang mengerjakan perkara yang ia perintahkan kepada murid-muridnya dan menjauhi perkara yang dilarangnya. Bentuk ini disebut kesempurnaan teladan. Contoh melakukan perbuatan dermawan, jujur, rendah hati dan lain sebagainya.

2. Seorang guru menerangkan apa yang ia sampaikan dengan penjelasan berupa tindakan, contoh : mengajarkan tata cara wudhu, sholat dengan turut serta melaksanakannya bersama anak-anak.

\footnotetext{
${ }^{9}$ Chabib Thoha,1996. Kapita Selekta Pendidikan Islam, Yogyakarta: Pustaka Pelajar

${ }^{10}$ Abdul Madjid dan Dian Andayani, op.ci

${ }^{11}$ Zuhairini, dkk.1993. Metodologi Pendidikan Agama, Solo: Ramadhani.

${ }^{12}$ Ati Sukmawati, Peran Guru dalam Pengembangan Moral bagi Anak Usia Dini, Artikel

Tadris IPA Biologi FITK IAIN Mataram, Volume VIII, Nomor 1, Maret - Juni 2015

${ }^{13}$ Wahyudin, Uyu dan Mubiar Agustin. 2011. Penilaian Perkembangan anak Usia Dini. Bandung: Refika Aditama.
} 
Pembelajaran untuk anak usia dini menggunakan prinsip belajar, bermain, dan bernyanyi. Pembelajaran anak usia dini diwujudkan sedemikian rupa sehingga dapat membuat anak aktif, senang dan bebas memilih. Anak-anak belajar melalui interaksi dengan alat-alat permainan dan perlengkapan serta manusia ${ }^{14}$

Metode merupakan cara yang efektif dan efisien untuk mencapai tujuan, berbagai metode yang perlu dilakukan agar pembelajaran pada anak usia dini dapat berjalan dengan efektif ${ }^{15}$ :

a. Metode demonstrasi, yaitu dengan cara menyampaikan pelajaran melalui representasi sebuah pertunjukan kepada anak-anak, melalui benda tertentu yang sedang dipelajari disertai dengan penjelasan lisan.

b. Metode dongeng, yaitu sebuah metode dengan cara menyampaikan pembelajaran dari kisah-kisah tau cerita-cerita yang mengandung moral tingii sehingga dapat mengubah cara pandang anak-anak dan mereka dapat mengambil hikmah dari kisah tersebut.

c. Metode wisata yaitu dengan cara mengajak anak-anak untuk meilhat tempat tertentu yang dapat mengubah minset atau pandangan mereka. Hal ini tidak sekedar rekreasi semata, namun untuk memperdalam pelajarannya dengan melihat kenyataan yang ada.

d. Metode keterampilan dapat digunakan untuk melatih anak-anak dalam memperoleh suatu, ketangkasan dan keterampilan. Metode ini juga merupakan cara yang baik untuk menanamkan kebiasaan-kebiasaan yang baik.

Selain itu, guru harus profesional dalam mendidik anak usia dini dengan menggunakan metode uswah (sebagai teladan) bagi anak, dan metode pengembangan sosial dan emosi melalui kegiatan pembiasaan, misalnya : setiap saat anak diajarkan 3S, senyum, sapa dan salaman. Seorang guru harus mempunyai sifat sopan, sabar dan senang dalam membentuk akhlak yang baik bagi anak. Pembiasaan $3 \mathrm{~S}$ ini, merupakan pembiasaan yang ditujukan untuk melatih keterampilan anak dalam berinteraksi dengan teman sebayanya dan juga dengan guru dan orang sekitarnya ${ }^{16}$ Pendidikan Agama Islam pada Anak Usia Dini. Sebagai upaya mempersiapakan perjalanan hidup seorang anak, maka pendidikan yag harus didapat yaitu: tarbiyah jismiyah, tarbiyah aqliyah, dan tarbiyah rohaniyah atau tarbiyah adabiyah. ${ }^{17}$

4. Kurikulum Pembelajaran

Kurikulum adalah suatu program pendidikan yang disediakan untuk membelajarkan siswa yang terdiri dari serangkaian pengalaman belajar dan di dalamnya terdapat sejumlah mata pelajaran yang harus ditempuh dan dipelajari oleh siswa dalam waktu tertentu untuk memperoleh sejumlah pengetahuan ${ }^{18}$.

Kurikulum merupakan rencana pendidikan yang memberi pedoman tentang jenis, lingkup dan urutan materi, serta proses pendidikan. Jika dikaitan dengan pendidikan Islam, maka kurikulum disusun untuk mewujudkan tujuan pendidikan Islam dengan memperhatikan tahap perkembangan peserta didik dan kesesuaiannya dengan lingkungan, kebutuhan pembangunan manusia Muslim seutuhnya, perkembangan ilmu pengetahuan dan teknologi. Tujuan yang hendak dicapai harus teruraikan dalam program yang termuat dalam kurikulum, bahkan program itulah yang mencerminkan arah dan tujuan yang ingin dicapai dalam proses pembelajaran.

Adapun pokok-pokok pendidikan atau kurikulum yang harus diberikan kepada anak, adalah meliputi seluruh ajaran Islam yang secara garis besar dapat dikelompokan menjadi tiga, yakni, aqidah, ibadah dan akhlak serta dilengkapi dengan pendidikan membaca Al Qur'an ${ }^{19}$.

\footnotetext{
${ }^{14}$ Wiyani, Novan Ardy. 2012. Format PAUD. Jogjakarta: Ar Ruzz Media.

${ }^{15}$ Syaiful Bahri Djamarah dan Aswan Zain.2002, Strategi Belajar Mengajar, Jakarta: PT Rineka Cipta,

${ }^{16}$ Wiyani, Novan Ardy. 2014. Mengelola \& Mengembangkan Kecerdasan Sosial \& Emosi Anak Usia Dini. Jakarta: Ar Ruzz Media.

${ }_{17}$ Zulfiana Herni,,2018. Pendidikan Agama Islam Pada Paud. Jurnal Tarbiyah UIN Sumatera Utara Medan. Vol.II No.1

${ }^{18}$ Hamalik, Oemar. 2008. Kurikulum dan Pembelajaran. Jakarta: Bumi Aksara

${ }^{19}$ Mansur. 2005. Pendidikan Anak Usia Dini dalam Islam. Yogyakarta: Pustaka Pelajar.
} 
a. Pendidikan akidah, hal ini diberikan karena Islam menempatkan pendidikan akidah pada posisi yang paling mendasar, terlebih lagi bagi kehidupan anak, sehingga dasar-dasar akidah harus terusmenerus ditanamkan pada diri anak agar setiap perkembangan dan pertumbuhannya senantiasa dilandasi oleh akidah yang benar. Di antara yang dapat dilakukan dalam memberi pendidikan aqidah kepada anak ialah dengan cara mengazankan anak yang baru lahir, sebagaimana diperintahkan rasul dalam sabdanya:

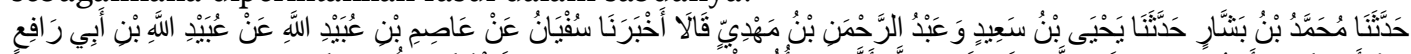

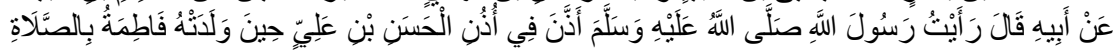

Artinya: "Dari Abu Rafi', ia berkata, "Aku melihat Rasulullah SAW azan sebagaimana ażan şalat, di telinga Husain bin Ali ketika Fathimah melahirkannya"(AR. at-Tirmiżi)

b. Pendidikan ibadah, hal ini juga penting bagi pertumbuhan dan perkembangan anak usia dini. Karenanya tata peribadatan menyeluruh sebagaimana termaktub dalam fiqih Islam hendaklah diperkenalkan sedini mungkin dan dibiasakan dalam diri anak sejak usia dini. Hal ini dilakukan agar kelak mereka tumbuh menjadi insan yang benar-benar takwa, yakni insan yang taat melaksanakan segala perintah agama dan taat pula dalam menjauhi segala larangannya.

Artinya : "Sesungguhnya kami menurunkan Kitab (Al-Qur'an) kepadamu (Muhammad) dengan (membawa) kebenaran. Maka sembahlah Allah dengan tulus ikhlas beragama kepada-Nya." (QS. Az-Zumar :2)

c. Pendidikan akhlak, dalam rangka mendidik akhlak kepada anak-anak, selain harus diberikan keteladanan yang tepat, juga harus ditunjukkan tentang bagaimana menghormati dan bertata krama dengan orang tua, guru, saudara (kakak dan adiknya) serta bersopan santun dalam bergaul dengan sesama manusia. Hal ini senada dengan Sabda Rasulullah:

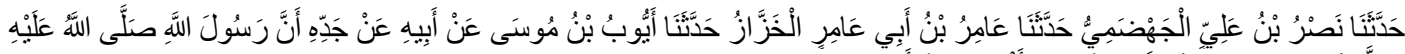

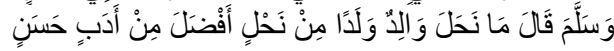

Artinya: "Tidaklah ada pemberian yang lebih baik dari seorang ayah kepada anaknya daripada akhlak yang baik" (R. Tirmizi)

5. Efektivitas Pembelajaran Agama Islam pada anak

Efektifitas berasal dari kata efektif, dalam kamus besar Bahasa Indonesia efektif berarti ada efeknya (akibat, pengaruhnya kesannya), dapat membawa hasil berguna. Pengertian efektifitas menurut Hidayat adalah suatu ukuran yang menyatakan seberapa jauh target (kuantitas, kualitas dan waktu) telah tercapai ${ }^{20}$, selain itu, menurut sadiman keefektifan pembelajaran adalah hasil guna yang diperoleh setelah melaksanakan proses belajar mengajar ${ }^{21}$.

Efektifitas adalah adanya kesesuaian antara orang yang melaksanakan tugas dengan sasaran yang dituju, juga dapat diartikan sebagai suatu organisasi yang mendapatkan dan memanfaatkan sumber daya dalam usaha mewujudkan tujuan operasional. Efektifitas juga merupakan pencapaian tujuan secara tepat atau memilih tujuan yang tepat dari serangkaian alternative atau menentukan pilihan dari beberapa pilihan lainnya. Efektifitas dapat juga diartikan sebagai pengukuran keberhasilan dalam pencapaian tujuan yang telah ditentukan Efektifitas pembelajaran agama islam pada anak usia dini, merupakan suatu ukuran keberhasilan yang menunjukan adanya perkembangan, perubahan sikap atau moral pada anak yang mencerminkan kegiatan islami. Berbagai penelitian, yang membuktikan bahwa pembelajaran agama islam pada anak usia dini berjalan efektif, dilihat dari beberapa penelitian dibawah ini :

\footnotetext{
${ }^{20}$ Hidayat, 2006, Teori Efektifitas Dalam Kinerja Karyawan, Yogyakarta, Gajah Mada University Press.

${ }^{21}$ Sadiman, Arief, dkk. 2002;, Meningkatkan efektivitas mengajar. Jakarta: Rineka Cipta.
} 
Pada penelitian (Endang dkk., 2017) menyatakan bahwa sekitar 96\% penanaman nilai agama islam pada anak usia dini terbilang efektif, anak-anaknya dapat melaksanakan berbagai kegiatan nilai agama seperti mengucapkan surat-surat pendek, doa harian, dan melakukan gerak, lagu, serta tepuk-tepuk Islami. ${ }^{22}$

Pada penelitian (Wiwit dkk., 2020) menyatakan bahwa hampir 100\% kegiatan pembelajaran agama islam yang dilakukan pada anak usia dini terbilang efektif, anak-anak dapat menerima berbagai macam metode pembelajaran yang telah diberikan oleh para guru terbukti dengan proses hasil wawancara dengan pihak orangtua. ${ }^{23}$ Pada penelitian (Syaeful, 2016) menyatakan bahwa pendidikan agama islam yang diberikan kepada anak usia dini efektif berjalan lancar terbukti dengan adanya peningkatan hasil belajar mereka yang dilihat dari proses penghafalan rukun iman, rukun islam serta surat-surat pendek. ${ }^{24}$ Pada penelitian (La Hadisi, 2010) menyatakan bahwa pendidikan ilmu ibadah yan diberikan kepada anak usia dini berjalan dengan sangat baik, mereka dapat memahami dan mengikuti secara baik apa yang telah diajarkan oleh para guru dengan begitu sangat efektif dilakukan. ${ }^{25}$ Pada penelitian (Herni, 2017) menyatakan bahwa pendidikan akhlak pada anak usia dini lebih efektif dilakukan dengan metode permainan dimana para guru menjelaskan dengan cara bernyanyi dan bermain bersama sehingga anak-anak lebih rileks dan ingat terus akan pembelajaran yang diberikan. ${ }^{26}$

Berdasarkan dengan data yang ditemukan diatas, maka pembelajaran agama islam yang diberikan kepada anak usia dini berjalan efektif dan terlihat signifikan dengan adanya peningkatan dari hasil belajar dan proses hasil wawancara dengan pihak orangtua. Oleh karena itu pembelajaran Agama Islam dapat diberikan dari anak usia dini secara teratur dan berkesinambungan untuk melihat perkembangan fungsi otak mereka, otak pada anak usia dini berkembang dengan pesat sehingga proses penyerapan ilmu pendidikan lebih mudah dibandingkan ketika anak sudah dewasa baru akan diberikan pembelajaran ilmu agama.

\section{Kesimpulan}

Pendidikan Agama Islam adalah proses mengubah tingkah laku individu peserta didik pada kehidupan pribadi, masyarakat, dan alam sekitarnya. Dasar pendidikan Islam ialah Islam dengan segala ajarannya yang tertuang dalam Al Qur-an dan Sunnah (hadis) Rasulullah SAW. Penetapan Al Qur-an dan Hadis sebagai dasar pendidikan Islam, hal ini dikarenakan kebenaran yang terdapat dalam kedua dasar tersebut dapat diterima oleh nalar manusia dan dapat dibuktikan dalam sejarah atau pengalaman kemanusiaan.

Fungsi dari pembelajaran agama islam pada anak usia dini yaitu meningkatkan kualitas moral keimanan serta ketakwaan seorang anak sejak usia dini kepada Allah SWT untuk mencari kebahagian dunia dan akhirat. Sedangakn tujuan pembelajaran Agama Islam yaitu untuk membentuk pribadi yang beriman dan bertakwa kepada Allah dan senantiasa meningkatkan keimanannya melalui pemupukan pengetahuan serta pengalamannya tentang agama Islam sehingga menjadi manusia muslim yang terus berkembang dalam hal keimanan dan ketakwaannya dalam berbangsa dan bernegara sehingga tercapai kebahagiaan di dunia dan di akhirat.

Pembelajaran agama islam memiliki berbagai metode yang efektif dan efisien untuk mencapai tujuan, berbagai metode yang perlu dilakukan agar pembelajaran pada anak usia dini dapat berjalan dengan efektif yaitu, Metode demonstrasi, Metode dongeng, Metode wisata dan Metode keterampilan.

Adapun pokok-pokok pendidikan atau kurikulum yang harus diberikan kepada anak, adalah meliputi seluruh ajaran Islam yang secara garis besar dapat dikelompokan menjadi tiga, yakni, aqidah, ibadah dan akhlak serta dilengkapi dengan pendidikan membaca Al Qur'an. Pembelajaran agama islam yang diberikan

\footnotetext{
${ }^{22}$ Endang dkk., 2017. Efektivitas Penanaman Nilai Agama Untuk Membentuk Persepsi Orang Tua Di Ra Darul Ulum. Jurnal PG-PAUD Tronojoyo. Vol.IV

${ }^{23}$ Wiwit dkk., 2020. Efektivitas Pembelajaran Pendidikan Agama Islam. AL-HIKMAH : Jurnal Pendidikan dan Pendidikan Agama Islam. Vol. 2 No.2

${ }^{24}$ Saeful, 2016. Efektifitas pembelajaran Pendidikan Agama Islam melalui Metode Made a match. Jurnal Tarbiyah Universitas Islam Bandung.

${ }^{25}$ La Hadisi, 2010. Efektifitas Pendidikan Karakter Pada Sekolah Anak Usia Dini: Studi Padatk Islam Terpadu AlQalam Kendari. Jurnal Tarbiyah IAIN Kediri.

${ }^{26}$ Zulfiana Herni, M.A. 2017. Pendidikan Agama Islam Pada Paud. Jurnal Tarbiyah UIN Sumatera Utara Medan
} 
kepada anak usia dini berjalan efektif dan terlihat signifikan dengan adanya peningkatan dari hasil belajar dan proses hasil wawancara dengan pihak orangtua. Oleh karena itu pembelajaran Agama Islam dapat diberikan dari anak usia dini secara teratur dan berkesinambungan untuk melihat perkembangan fungsi otak mereka, otak pada anak usia dini berkembang dengan pesat sehingga proses penyerapan ilmu pendidikan lebih mudah dibandingkan ketika anak sudah dewasa baru akan diberikan pembelajaran ilmu agama.

\section{Referensi}

Al-Qur'an dan Terjemahnya. 2015. Departemen Agama RI. Bandung: CV Darus-Sunnah

Ati Sukmawati, Peran Guru dalam Pengembangan Moral bagi Anak Usia Dini, Artikel

Chabib Thoha,1996. Kapita Selekta Pendidikan Islam, Yogyakarta: Pustaka Pelajar

Danial dan Wasriah. 2009. Metode Penulisan Karya Ilmiah. Bandung: Laboratorium Pendidikan Kewarganegaraan UPI.

Endang dkk., 2017. Efektivitas Penanaman Nilai Agama Untuk Membentuk Persepsi Orang Tua Di Ra Darul Ulum. Jurnal PG-PAUD Tronojoyo. Vol.IV

Hamalik, Oemar. 2008. Kurikulum dan Pembelajaran. Jakarta: Bumi Aksara

Hidayat, 2006, Teori Efektifitas Dalam Kinerja Karyawan, Yogyakarta, Gajah Mada University Press.

Isjoni,2010. Model Pembelajaran Anak Usia Dini Bandung: Alfabeta

La Hadisi, 2010. Efektifitas Pendidikan Karakter Pada Sekolah Anak Usia Dini: Studi Padatk Islam Terpadu Al-Qalam Kendari. Jurnal Tarbiyah IAIN Kediri.

Lihat Abuddin Nata,1999. Metodologi Study Islam, Cet. I; Jakarta: PT. Raja Grapindo Persada

Mansur. 2005. Pendidikan Anak Usia Dini dalam Islam. Yogyakarta: Pustaka Pelajar.

Omar Mohammad Al-Thoumy Al-Syaibany,1979. Filsafat Pendidikan Islam, Terjemahan Hasan Langgulung, Jakarta: Bulan Bintang

Pasiak, Taufik. 2009. Unlimited Potency of The Brain: Kenali dan Manfaatkan. Sepenuhnya Potensi Otak Anda yang Terbatas. Bandung: PT Mizan.

Sadiman, Arief, dkk. 2002;, Meningkatkan efektivitas mengajar. Jakarta: Rineka Cipta.

Saeful, 2016. Efektifitas pembelajaran Pendidikan Agama Islam melalui Metode Made a match. Jurnal Tarbiyah Universitas Islam Bandung.

Sugiyono. 2011. Metode Penelitian Kuantitatif, Kualitatif dan R\&D. Bandung: Afabeta

Suyadi. 2014. Teori Pembelajaran Anak Usia Dini. Bandung : PT. Remaja

Syaiful Bahri Djamarah dan Aswan Zain.2002, Strategi Belajar Mengajar, Jakarta: PT Rineka Cipta,

Tadris IPA Biologi FITK IAIN Mataram, Volume VIII, Nomor 1, Maret - Juni 2015

Wahyudin, Uyu dan Mubiar Agustin. 2011. Penilaian Perkembangan anak Usia Dini. Bandung: Refika Aditama.

Wiwit dkk., 2020. Efektivitas Pembelajaran Pendidikan Agama Islam. AL-HIKMAH : Jurnal Pendidikan dan Pendidikan Agama Islam. Vol. 2 No.2

Wiyani, Novan Ardy. 2012. Format PAUD. Jogjakarta: Ar Ruzz Media.

Wiyani, Novan Ardy. 2014. Mengelola \& Mengembangkan Kecerdasan Sosial \& Emosi Anak Usia Dini. Jakarta: Ar Ruzz Media.

Zuhairini, dkk.1993. Metodologi Pendidikan Agama, Solo: Ramadhani.

Zulfiana Herni, M.A. 2017. Pendidikan Agama Islam Pada Paud. Jurnal Tarbiyah UIN Sumatera Utara Medan

Zulfiana Herni,,2018. Pendidikan Agama Islam Pada Paud. Jurnal Tarbiyah UIN Sumatera Utara Medan. Vol.II No 